\title{
AN ASSESSMENT OF THE SOCIAL WORK PROGRAM IN TURKEY IN TERMS OF LABOUR MARKET EXPERIENGE AND PROFESSIONAL SKILL ATTAINMENT
}

\author{
Bulent Arpat ${ }^{1}$, Mete Kaan Namal ${ }^{2}$, Mustafa Kocanci ${ }^{3}$ and Aynur Yumurtaci* \\ 1) Bandirma 17 September University, Ballkesir, Turkey \\ ${ }^{233)}$ Akdeniz University, Antalya, Turkey \\ ${ }^{4)}$ Istanbul University, İstanbul, Turkey
}

Please cite this article as:

Arpat, B., Namal, M.K., Kocanci, M. and Yumurtaci, A., 2021. An Assessment of the Social Work Program in Turkey in Terms of Labour Market Experience and Professional Skill Attainment. Amfiteatru Economic, 23(57), pp.548-569.

\section{Article History}

Received: 3 November 2020

Revised: 25 January 2021

Accepted: 22 March 2021

\section{DOI: $10.24818 / \mathrm{EA} / 2021 / 57 / 548$}

\begin{abstract}
Dominance of theory-based education is not well connected by the current practices. So, the knowledge delivered within higher education institutions cannot create adequate value in the market and in turn which causes the youth unemployment to become a chronicle problem. Therefore, work placement opportunities within higher education create significant advantages during the transition to the labour market. This study aims to evaluate the efficiency of the Social Work Program in Turkey, in which students work at public institutions during their university education to gain experience, professional skills, and knowledge about the labour market. The research makes use of mixed methods and a crosssectional approach. In terms of the research analysis, descriptive and inferential methods, as well as content analysis, are utilized. The findings show that, while the Social Work Program procured remarkable attainments for the students about the labour market, it is mostly inadequate for professional skill-building. The reason, it is determined as a lack of overlap between the students' field of education and their designated work placement. If the program is redesigned according to this approach, it might be predicted to become prominent as an active and robust workplace policy in fighting youth unemployment.
\end{abstract}

Keywords: youth unemployment, social work program, utility program, professional skills, labour market.

JEL Classification: E24, R23, J2, J21 * Corresponding author, Aynur Yumurtaci - e-mail: aynur.yumurtaci@ gmail.com
This study has been presented at the VII. International Strategic Researches Congress (ISRC) as an oral
presentation.

\section{Authors' ORCID:}

Bulent Arpat: orcid.org/0000-0002-3512-9969

Mete Kaan Namal: orcid.org/0000-0002-0937-8355

Mustafa Kocanci: orcid.org/0000-0002-3950-3532

Aynur Yumurtaci: orcid.org/0000-0003-0277-5750 


\section{Introduction}

As an essential factor of material and non-material development, education has a vital function in creating a qualified labour force and making it easier for individuals to enter the labour market (Ozguler, 2019). However, young people in higher education who take place in the final and efficient link of schooling are more disadvantaged than the other groups in the matter of facing unemployment during the transition from school to the labour market. With the working conditions gradually worsening and turning into vulnerable employment, problems, especially about employment and unemployment, become prominent for university graduate young people nowadays. During the transition of young graduates into the labour market, low wages, lack of experience, and their qualifications falling short of labour force demands cause this group to come face to face with important problems transitioning into the labour market (Cansever and Namal, 2019). Social Work Program (SWP) is a program created to solve this problem and aid the economic situation of higher education students (Arpat, 2020). The program is based on having higher education students (excluding distance education and postgraduate students) get to know work-life and gain work discipline by working at public institutions for a maximum of three months within June, July, August, and September. The students work in public workplaces, which undertake environmental protection, restoration, protection and introduction of the cultural heritage, maintenance and organization of the libraries and supporting the cultural and social services of the public institutions (Regulation of the Amendment of the Active Workforce Services Code, 2018 )Unemployment is both an individual and social problem that has been presented since the expansion of the labour force for production, and it has exponentially grown against all economic and social precautions in the last century (Kumas, 2001). It may occur because of the lack of labour force demand and workplaces, non-operation of the current workplaces, low wages, and workers not having the necessary skills and abilities for the job (Koklu, 1984). Therefore, the present research focuses on the supply aspect of the labour market. One of the critical life stages sustaining the development of the skills and abilities is the university education stage. In the context of the relationship between education and unemployment, it is stated that unemployment will decrease as the education level rises (Gursel and Ulusoy, 1999). However, despite the increase in education level, the expected decrease in unemployment does not occur (Bozdaglioglu, 2008).

Thus, there is a high unemployment rate among university graduates. The reasons for this are:

- The theoretical education is not well connected to the current practices, the knowledge delivered within higher education cannot create adequate value in the market (Ozdemir, 2012).

- University graduates look for jobs with higher pay than their elementary school or high school graduate counterparts and thus remain unemployed longer (Guney, 2019). Active Labour Market Policies (henceforth ALMP) that help solve these problems and help university graduates get to know and experience the working life and gain adequate professional skills are becoming more critical. In this way, it will be possible for university graduates to achieve decent work opportunities in line with their expectations and qualifications within the primary labour market. The number of university graduate unemployed people in Turkey is overwhelmingly high. According to the Turkish Employment Agency (TEA) data, as of April 2020, there are 370,169 unemployed people with associate degrees and 565,265 with bachelor's degrees registered in their database. The ratio of registered associate and bachelor's degree-owning unemployed people is $26 \%$ out of all registered unemployed people, which shows that a quarter of the registered people awaiting employment is university graduates (TEA, 2020a). The university 
graduate unemployment is within the scope of youth unemployment. The rate of youth unemployment in Turkey is $24.4 \%$, and the number of unemployed young people is $1,032,000$ (TURKSTAT, 2020b).

This research aims to assess the SWP in Turkey, wherein students work at public institutions throughout their university education to gain experience, professional skills, and knowledge about the labour market. Our study carries importance because it provides in-depth information with help of survey analysis about the impact of ALMP and SWP in the fight against youth unemployment. The first part of the study deals extensively with the labour market in Turkey and SWP. The second part analyses the problems of university graduates during their transition into the labour market. The third part explains the methodology, and finally, the fourth part demonstrates and discusses the findings before moving onto the conclusion and policy suggestions.

\section{Social Work Program and youth unemployment in Turkey}

\subsection{The origin and the characteristics of the Social Work Program}

SWP is an implementation that intersects in many aspects with the Public Beneficiary Program (henceforth PBP), which has been in effect since 1999. The difference between SWP and PBP is that the people employed are university students. With the amendment made to the PBP in summer 2019, a limited number of university students have been added to the scope, and this amendment has been named as SWP. Within the range of SWP, basic activities, such as gathering student preferences, choosing the number of students as per the quota, work placements, and wages, are handled via TEA. The aim of the program is for university students to get to know and experience the working life and gain work discipline. In this sense, an essential expectation from the SWP is for it to create a solution to the high unemployment rate among university graduates and young people.

To better understand the SWP, it is necessary to understand the procedures, fundamentals, and the purpose of the PBP. PBP is one of the ALMPs implementation, which develops a qualified labour force, raise the employment rate, and decrease the unemployment rate. This program is put to action extensively by TEA, which provides employment services for the general public (Askin and Askin, 2017). The primary target groups of the PBP, which is a component of the creation of demand-side employment policies between ALMPs are young people, long term unemployed people, women, elderly, the disabled, and refugees that do not have a high chance of employment (Usen, 2007). Due to the high cost of ALMPs, only these groups are included in the program. Thus, instead of all unemployed people, people who are under-qualified, who do not have extensive work experience and/or people who have been unemployed long term. The other characteristic of these groups is that they are all at a disadvantage when it comes to first time employment or re-employment after a long period (Vazquez-Alvarez, 2004). PBP is especially implemented after an economic recession or crisis to lessen the severity of the rising unemployment and poverty (Dar and Tzannatos, 1999). With the program, the unemployed people are employed temporarily in jobs which creating within the public sector. The created jobs are usually about infrastructure, protecting and bettering the environment, the maintenance and repair of public places, healthcare and welfare services, and municipal services (Evans-Klock, et al., 1998; Kapar, 2005). According to the TEA data, 6,322 PBP (including the SWP) programs have been started in 2019. It is stated that 309,373 people have benefited from these programs. $127,152(41.1 \%)$ of these 
people were male and 182,221 (58.9\%) were female (TEA, 2020b). This number includes the 20,172 university students who also took part in the scope of SWP. The jobs within PBP are usually criticized for being irregular, lacking social security, low paying, and unable to relieve poverty (Gun, 2013). According to previous studies, the programs have short-term positive effects, but are unable to create positive results for the attendants' position in the workplace in the long term (Erhel, et al., 1996; Dar and Tzannatos, 1999; Caliendo and Schmidl, 2016; Askin and Askin, 2017).

The fundamentals of SWP are evaluated on below in terms of experiencing the labour market and gaining professional skills:

- Utilization period: It is applied maximum 3 months. While this period makes it possible for the participants to take part in the scheme more than once, it is limited to 90 days throughout the university experience. A maximum of 42 days of work is allowed in one term. It can be argued that the longer the student stays within the program, the more he/she gets to know and experiences the labour market. Accordingly, previous research on long term work placements (implemented under different names) that take place within the university curricula also supports this claim (Saribiyik, 2013; Arpat, 2018). In the findings of the aforementioned studies, it is understood that the gained professional skills increase as the duration of the program increases.

- Application window: During the implementation period of SWP, students with ongoing classes, and students who are doing a mandatory internship cannot benefit from this program. Having the placement outside the classwork period and having the students do the placement full-time can help them better concentrate on the placement without the burden of theoretical classwork, and in turn, can help get to know and experience the labour force as well as acquire better professional skills.

- Working period: It is set forth for the students to work at the workplaces for three days a week and 8 hours a day. Even though three days a week seems short, it looks sufficient when we consider the total implementation period for getting to know and experiencing the labour market and acquiring better professional skills. On the other hand, students having the same 8-hour workday with the permanent/contractual workers is regarded to be a sufficient timeframe to actualize the aforementioned purposes.

- Leave period: During the practice, the students have a right to 5 days of unpaid leave. Granting the students with this right may help them with getting to know and experiencing the labour market and acquiring better professional skills as well as increase their work performance.

- Wages: The students get paid an amount calculated by having the minimum wage multiplied by the working days. No payment is made for the weekends and the off days. A transparent wage system that is based on rules and shaped by skills and abilities is an important motivational factor for the individual and an element that increases the labour force performance and productivity (Balta, 2007). Thus, having the students' payments at the same level as a worker on the minimum wage level is possible to aid the aforementioned purposes with the high-level motivation it will provide.

When the work relationship variables explained above are evaluated as a whole, it is considered possible for the university students to carry out the SWP practices to get to know 
and experience the labour market as well as acquire better professional skills to make a satisfactory contribution.

Specific additional criteria must also be met to benefit from SWP. Below are the conditions where the students' SWP applications will be rejected:

- Applicants who have an ongoing internship, who work within the scope of long term insurance programs or who state being insured by only short term insurance programs from another workplace at the date of application or the period of the program,

- Students who have a GPA below 2.00 out of 4.00 or below 53.33 out of 100 (TEA, 2019b).

According to these criteria, those who are in mandatory university internships and full or part-time workers are excluded from the program during these times. In addition, it is observed that students with low academic performance are also excluded from the SWP application. When the irrelevance between a student's professional knowledge and experience gained by workplace practices and academic performance is taken into account, the 53.33 point academic achievement criteria is an important restraint against students with low academic performance who have a potential to raise their professional performance (Aksit, Arpat and Kalfa, 2017).

\subsection{Youth unemployment amongst university graduates and the Social Work Program}

Unemployment is a situation described as an individual's inability to find employment despite being willing to work and using all manners of job hunting (Akyildiz, 2019). On the other hand, unemployment at the social level is defined difference between the number of labour force and the number of people employed in the labour market in a country (Zaim, 1997). At the same time, it is described as a part of the productive forces' inability to find a place within the labour market (Erkol, 2012). Unemployed is defined as a person who is willing and able to work within the current wage range but cannot find a reasonable and suitable job (Yavuz, 2010). Turkish Statistical Institute (TURKSTAT, 2020a) describes unemployment as in following:

individuals at the age of 15 and above who have approached at least one channel of employment and can start working in 2 weeks which has been unemployed in the reference period (people who have never worked at a workplace in exchange of profit, daily wage, by the wage of or free of charge and have no connection with a workplace whatsoever) are included in the unemployed population (TURKSTAT, 2020a).

Meanwhile, an unemployed young person is defined as an individual between the ages of 15-24 who have not worked more than one hour in the reference period but ready to start working and actively looking for a job (Ata, 2007; Murat and Sahin, 2011). According to February 2020 data, the rate of youth unemployment in Turkey is $24.4 \%$ (TURKSTAT, 2020 b). In Turkey, the ratio of unemployment in associate and bachelor degree owners is twice as high compared to other groups (Arpat, 2018). According to International Labour Organization (ILO) data, youth unemployment is 2.9 times higher than the ratio of adult unemployment (ILO, 2015). While demand for skilled labour is increasing in Turkey, it has seen that there is a mismatch between labour demand and labour supply in the context of competence dimension (Izgi, 2012). Taking this into account it is expressed that the 
vocational education could not be conducted as per the market's desired quality and attributions and the education-employment connection could not be established (Bozdaglioglu, 2008). SWP can resolve these disadvantages with the right policies and practices. On the other hand, it is known that young people usually quit work because of dissatisfaction with their primary positions and their current/future earnings; while the employers terminate the work contract because of lack of experience, lack thereof or noncompatibility of the skills, unable to meet the wage expectations and the lesser cost of termination (Secer, 2006). SWP may eradicate the reasons for termination both for the workers and bosses with the advantage of getting to know and experience the working life.

When the reasons for termination mentioned above are taken into account, it may not seem possible for the SWP to directly solve the problems students will face in the labour market such as low wages, lack of experience, and other qualification incompatibilities. But the practice may help the students to experience possible workplace problems and build necessary coping skills. Furthermore, it may help students gain an awareness to understand the difficulties of working life on the basis of communications and interactions with the other workers and thus develop suitable attitudes. When it is taken into account that there are only short term internships within the curricula of most associate and bachelor's degrees, some high education curricula do not even contain internships; it could be said that SWP will create a significant opportunity to get to know and experience the working life. On the other hand, it is highly emphasized that the correlation between university education and vocational education is getting less and less essential to succeed in working life. In another way, it is asserted that there are findings proving building professional skills without academic education creates better options in the labour market (Lerman, 2013). Even this assertion shows that by making the SWP to help the students' vocational skills, it can create better opportunities for them to find employment after graduation.

It is asserted that the effect of the ALMPs' on the employment and the cost-effectiveness is dependent on the design of the AWMPs (Brown and Koetti, 2015). According to this it could be said that the variables such as the number of the benefits, the quality of the work done and compatibility with the education, the terms for utilization and wage limits will affect the success of the program. On the other hand, it is emphasized that if the ALMP expenses are low, youth unemployment may occur or could not be prevented (Marques and Hörisch, 2019). Thus it is possible for a little budget SWP practice with limited entry to have an only marginal effect on the youth unemployment independent of the student preferences. According to another data backing up this claim, it is asserted that if the government expenditure is insufficient compared to private initiatives, unemployment occurs-grows (Kaboub, 2007, narrated by Ozdemir, 2019, p. 2540). Taking these data into account, it is possible for a SWP design with higher participation will create an effect of decreasing youth unemployment.

\subsection{The possible effects of the Social Work Program on the labour force}

The active population of a country is the total of people within and out of the labour force. SWP is an implementation expected to contribute to the groups of people who are employed, unemployed, and out of the labour force which shows in the (figure no.1). 


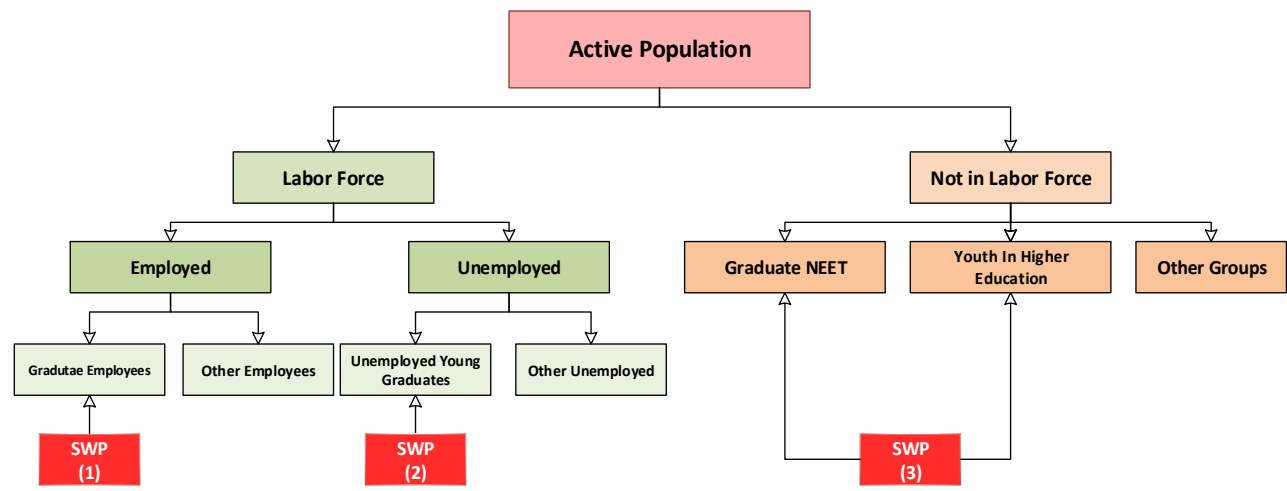

Figure no. 1. The scope of active population and the groups in which the Social Working Program is expected to create a positive effect

Source: Adapted by the authors from Gundogan, 2013.

The possible positive effects of the SWP on these groups are explained as follows:

- Effect on employment: SWP has two positive effects on the employment of university graduates. The first being the graduates' possibility of finding work in better quality jobs. After graduation, students are expected to have the chance to work in jobs with better pay and higher working conditions, with the positive effects of SWP. It also allows the graduate to transition into a position more relevant to his education. One of the fundamental conditions required to find a job related to one's expertise is experience. The SWP can be used to help university graduates find a post relevant to his education by matching him with a suitable workplace. If not handled properly, however, SWP could even cause the graduate to face unemployment, as well as not making any contribution towards his transition into a workplace or finding a suitable job. In other words, even if these graduates can find employment opportunities within the labour market, they may have to work in insecure jobs with low wages and/or informal sector which is unrelated to their education. Thus when the National Employment Strategy of the Republic of Turkey is analyzed, it can be seen that the education-employment connection is given a high level of priority. In the document, it is stated that it is the education system's responsibility to supply the qualified labour force that the labour market needs and to continually enhance current skills and abilities (Ministry of Family, Labour and Social Services, 2017) SWP as a practice, demonstrating that the government also contributes to the execution of the obligations given to the educational institutions. In order to get the maximum benefits from these practices, a policy of choosing suitable students for SWP and taking education relevance into account should be adopted.

- The effect on youth unemployment: SWP can eliminate or lessen the probability of unemployment by providing college students who face post-graduation unemployment the opportunity to get to know and experience the labour market, especially in economies with high unemployment rates such as Turkey. Also, through these policies, university students will have the chance to experience working within the labour market and increase their professional skills during their student years. 
- The effect on groups out of the labour force: Groups out of the labour force include students, retirees, home-makers, seasonal workers, and those who cannot work because of disability, illness, and old age. SWP can also employ groups outside this definition, such as students in ongoing education (those who are willing to work but not looking for a job) and university graduates Not in Employment, Education or Training (NEET). The probable effects of SWP on these two groups are explained as follows:

- Continuing University Studies: Students within secondary education (evening school) prefer to work part-time or full time in the morning hours. Students in this group who are willing can have the option of working before they complete their university education using the experience and skills gained through the SWP. Indeed, Karadeniz and Kumas (2016) shows that $44 \%$ of senior students who undertake long-term vocational education within the labour force receive business offers. Also, this rate is $37 \%$ in the study of Arpat, et al. (2017).

- Unemployed university graduates who gave up looking for a job because of repeated failure in finding one, but they are ready to start working who are included within the out of labour force group, are categorized as other. These individuals are also named discouraged workers. Within this group, people who are not employed nor studying have an important place and include young university graduates (NEET). ${ }^{i}$ SWP practices can save this students from entering the NEET category. Thus, the students will get to know the qualities, characteristics, and necessary skills required by the labour market, and at the same time, gradually attain them through professional experience in the workplace.

As can be seen, SWP is a procedure capable of obtaining solutions to problems such as university graduates not being able to find a job (youth unemployment), and increasing the quality of the labour force, provided it is implemented well. Likewise, unemployment (especially youth unemployment) is the first and foremost macroeconomic problem area for all countries, whatever their development stage is (Isik, 2019). Furthermore, as unemployment has become chronic in the young population, some of these groups are starting to be referred to as disadvantaged (Cansever and Namal, 2019). According to the research of Arpat (2018), which is based on TURKSTAT data, the percentage young people between the ages of 15 and 24 holding an associate degree is $26.6 \%$, three times higher than their peers. When the number of young people who are discouraged about finding a job is also taken into account, the unemployment rate of associate and bachelor degree graduates is stated to rise to $40.6 \%$. It is highly essential to enable these young people to join the labour market through ALMPs. If SWP is applied with a view of helping this group to get to know and experience the work environment and to gain professional skills, it can become an effective kind of ALMPs that will ensure employments rates rising after graduation.

\section{Methodology}

The aim of this research is to recognize SWP applications and analyze the effects of these applications on students. Thus, it will be evaluated through the eyes of students who have

i Turkey has the highest young NEET population amongst OECD member countries (Tas, et al., 2018), standing at $26.7 \%$ as of February 2020 (TURKSTAT, 2020b). 
experienced the practice of how SWP serves its mission. The research questions are as follows:

- Did the SWP practice contribute towards the students getting to know the labour market?

- Did the SWP contribute towards the students' developing their professional skills in their area of expertise?

- What are the SWPs needs for reformation? Do university students think that SWP is a useful application?

The study is designed under the cross-sectional and mixed methods. Cross-sectional research aims to observe a sample during a certain timeframe (Tutar, 2020). The primary principle in mixed methods research is expressed as gathering multiple data using different strategies, methods, and approaches (Johnson and Turner, 2003). By using both quantitative and qualitative approaches together, researchers can better understand and solve the problems compared to using only one of these approaches (Creswell, 2006) and different views and understandings that could be otherwise overlooked are brought into the light (Johnson and Onwuegbuzie, 2004). Mixed methods research also used for increasing the generalization of the data (Baki and Gokcek, 2012). By using mixed methods study, we thoroughly analyze whether the SWP practices as a whole serve the purpose of getting to know and aim to generalize these findings with more certainty.

The SWP was put into practice for the first time in Turkey during the June-September 2019 period. 20,000 students benefited from it in the first year. According to this, the research population comprised of 20,000 students. In the instance of a 20,000 person, the primary audience, the population size is calculated to be 377 participants for a $95 \%$ confidence interval with a 5\% error margin (Krejcie and Morgan, 1970). Based on this, a student group of 500 people from seven regions of Turkey has been randomly chosen for research (figure no. 2).

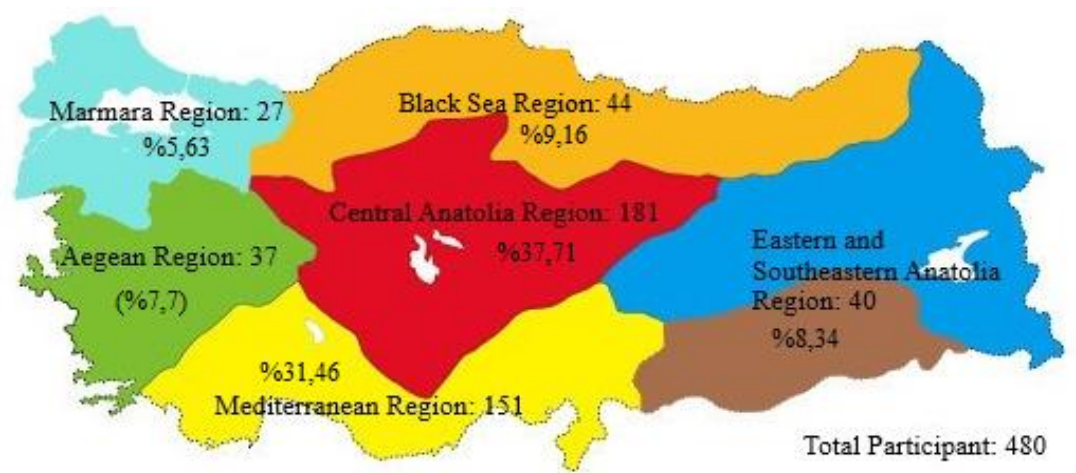

Figure no. 2. The regional distribution of the cities where the participants worked

In this study, questionnaire has been used for data collection. The questionnaire consists of three parts. In the first part, eight questions with 5-point Likert scale answers have been directed to students in order to determine the SWP's performance in getting to know and experiencing the workplace. The second part, it has comprised of 10 questions to specify the participants' demographic characteristics and correspondence of the work and the areas where they are studying. As a last part, within the survey form, two open-ended questions 
have been directed to the participants. One of these questions is how they express the overlap and dissociation of the workplace and study area. The second question is what their criticisms are towards SWP. The given answers have not turned into quantitative data by coding of the research, thematic and illustrative analyses were used for strengthening the data during the arguing of the quantitative data.

The SWP research has done after the commencement of the 2019-2020 educational term after its first application in the summer of 2019. The reason for this particular timing as the start of the education term is that the practice had just been completed, and the students still had bright and fresh opinions about it. The questionnaire collection ended in November 2019 after the target sample size was reached. The contact information of the participants provided by TEA. Also, the survey conducted online. Most of the students participated in the survey via mobile devices. The quantitative and qualitative data within the research design obtained simultaneously with the questions included in the same questionnaire. The data analysis was carried out with independent use of methods within quantitative and qualitative approaches. In the quantitative approach, descriptive and inferential technics were designed. Similarly, the data gathered from open-ended questions were used to support the quantitative figures directly with the applicants' statements. The descriptive methods used were frequency and percentage analysis, mean, mode, median and standard deviation. For the inferential analysis, independent samples t-test was used. In terms of qualitative analysis, content analysis was made, and a word cloud was generated. Before the creation of the word cloud, similar/synonymous concepts were recorded by stating a joint concept that indicates the same meaning. The Cronbach's alpha consistency reliability coefficient of internal consistency is used to estimate the internal consistency of the tools by that use a Likert-type weighted score (Okursoy and Turan 2014). In this study, the Cronbach's alpha value has been found to be 0.750. Tests with a Cronbach's alpha coefficient between 0.70 and 0.80 is considered to have very good reliability (Nunnaly, 1978; Alpar, 2011). Since the Cronbach's alpha coefficient of the questionnaire is between the given ranges, it is decided that it is possible to apply statistical analysis on the data gathered from the survey.

\section{Findings}

When the demographic data are examined, it is observed that there are more females $(70.2 \%)$ than males. Also, there are more 21 years and above students $(60.2 \%)$ than 18 -20-year-olds. Meanwhile, equal weight students $(41.7 \%)$ constitute a more dominant group than others. In addition, students with a GPA between 2.51-3.00 (35.8\%) are the most remarkable group (table no. 1).

Table no. 1. Demographic characteristics of the students

\begin{tabular}{lccccc}
\hline \multicolumn{1}{c}{ Groups } & Frequency & $\%$ & Groups & Frequency & $\%$ \\
\hline \multicolumn{4}{c}{ Main Field of study } & & \multicolumn{3}{c}{ GPA (On a Scale of 4) } \\
Math & 122 & 25.4 & & & \\
Verbal & 81 & 16.9 & $\mathbf{2 . 0 0 - 2 . 5 0}$ & 112 & 23.3 \\
Equal Weight & 200 & 41.7 & $\mathbf{2 . 5 1 - 3 . 0 0}$ & 172 & 35.8
\end{tabular}




\begin{tabular}{|c|c|c|c|c|c|}
\hline A & \multicolumn{5}{|c|}{$\begin{array}{l}\text { An Assessment of the Social Work Program in Turkey in Terms } \\
\text { of Labour Market Experience and Professional Skill Attainmen }\end{array}$} \\
\hline Groups & Frequency & $\%$ & Groups & Frequency & $\%$ \\
\hline \multicolumn{3}{|c|}{ Main Field of study } & \multicolumn{3}{|c|}{ GPA (On a Scale of 4) } \\
\hline $\begin{array}{l}\text { Basic } \\
\text { Competences* }\end{array}$ & 58 & 12.1 & 3.01-3.50 & 118 & 24.6 \\
\hline Linguistics & 19 & 4.0 & $3.51-4.00$ & 78 & 16.3 \\
\hline Total & 480 & 100.0 & Total & 480 & 100.0 \\
\hline \multicolumn{3}{|c|}{ Gender } & \multicolumn{3}{|c|}{ Age } \\
\hline Male & 143 & 29.9 & Between 18-20 & 191 & 39.9 \\
\hline Female & 337 & 70.2 & 21 and above & 289 & 60.2 \\
\hline Total & 480 & 100.0 & Total & 480 & 100.0 \\
\hline
\end{tabular}

Meanwhile, the students ideas about SWPs contribution to get to know the market have been evaluated by the 5-point Likert scale at the level of I agree (59.4\%). When the options I agree and I completely agree are evaluated together, this ratio reaches $81.1 \%$. The median score on this item is 3.9813 (table no. 2). This score represents a high level on the interval scale in a 5-point scale ${ }^{\mathrm{ii}}$. It is possible to say that SWP fulfilled an important function towards the university students in getting to know the working life. According to this, the students had the opportunity to get to know and experience working life in public workplaces.

Table no. 2. SWP's Contribution in Getting to Know the Labour Market

\begin{tabular}{|c|c|c|c|c|c|}
\hline & Frequency & $\%$ & $\%$ & $\bar{x}$ & Median \\
\hline I completely agree & 104 & 21.7 & \multirow{2}{*}{81.1} & \multirow{2}{*}{3.9813} & \multirow{2}{*}{$\begin{array}{c}4 \\
\text { (I Agree) }\end{array}$} \\
\hline I agree & 285 & 59.4 & & & \\
\hline $\begin{array}{l}\text { Neither agree nor } \\
\text { disagree }\end{array}$ & 79 & 16.5 & 16.5 & Mode & S.D. \\
\hline I disagree & 2 & 0.4 & \multirow{2}{*}{2.5} & \multirow{3}{*}{$\begin{array}{c}4 \\
\text { (I Agree) }\end{array}$} & \multirow{3}{*}{0.76569} \\
\hline I completely disagree & 10 & 2.1 & & & \\
\hline Total & 480 & 100.0 & 100.0 & & \\
\hline
\end{tabular}

ii The Likert component of 5 has a range of 4 points. This range has been split into five equal parts and interpreted as between 1.00-1.79 is "very low", 1.80-2.59 "low", 2.60-3.39 "average", 3.40-4.19 "high", 4.20-5.00 "very high" (Yurekli and Kalfa, 2016). 
SWP has created a significant change in students' ideas about the work market's characteristics and entering the labour market. This change in students' ideas can be attributed to the fact that they did not have any previous theoretical and practical knowledge about the work market. It is understood that SWP has changed the ideas of $47 \%$ of the students' about the work market. While out of $33.8 \%$ of students are unsure about it, $19.2 \%$ of the students have not changed in their ideas. The median of 3.36 corresponds to a score that is close to the high level on the scale (table no. 3).

Table no. 3. The degree to which SWP has changed the students' ideas about the labour market

\begin{tabular}{|c|c|c|c|c|c|}
\hline & Frequency & $\%$ & $\%$ & $\bar{x}$ & Median \\
\hline I completely agree & 65 & 13.5 & \multirow[b]{2}{*}{47.0} & \multirow[b]{2}{*}{3.3688} & 3 \\
\hline I agree & 161 & 33.5 & & & $\begin{array}{c}\text { (Nor agree Nor } \\
\text { disagree) }\end{array}$ \\
\hline $\begin{array}{l}\text { Neither agree nor } \\
\text { disagree }\end{array}$ & 162 & 33.8 & 33.8 & Mode & S.D. \\
\hline I disagree & 70 & 14.6 & \multirow{2}{*}{19.2} & \multirow{3}{*}{$\begin{array}{c}3 \\
\text { (Neither agree } \\
\text { Nor disagree) }\end{array}$} & \multirow{3}{*}{1.03562} \\
\hline I completely disagree & 22 & 4.6 & & & \\
\hline Total & 480 & 100.0 & 100.0 & & \\
\hline
\end{tabular}

For students the idea of finding a job is difficult or not after graduation has been evaluated. In this context, how much awareness students have reached regarding the transition to labour force and difficulties during employment has been analyzed by SWP applications. The students think that being employed is hard after the SWP experience (52.6\%). $21.3 \%$ of the students are undecided whether they will find a job after SWP. Moreover, $27.1 \%$ of the students have not assessed the transition into the work-life as difficult (table no. 4). The reasoning for the latter $27.1 \%$ of the group could be interpreted as them having done a work placement with better correspondence to their field of education compared to the other students, and because of them having better The Higher Education Institutions Examination $(\mathrm{YKS})^{\mathrm{iii}}$ scores and thus pursue their education in better-qualified universities. Another reason for this finding could be that these students had prior work experience with pay. Indeed, when this $27.1 \%$ is analyzed, it was found that $47 \%$ of these students have GPAs over 3.00 (out of 4.00), and the remaining 53\% have GPAs under 3.00.

iii The Higher Education Institutions Examination is made for student's selection to the university. YKS is conducted by Measurement, Selection and Placement Center (OSYM) in order to place students in higher education institutions on the basis of their preferences depending on their exam score. YKS covers 3 sessions. First Session of YKS is the Basic Proficiency Test (TYT). Attending the first session is mandatory for all candidates. The second session includes the Field Proficiency Test (AYT) and the third session covers the Foreign Language Test (YDT). These two sessions are optional to attend. The TYT includes the Turkish Test, Social Sciences Test, Basic Mathematics Test and Science Test. The AYT covers the Turkish Language and Literature-Social Sciences-1 Test, Social Sciences-2 Test, Mathematics Test and Science Test. YDT contains the German, Arabic, French, English and Russian tests. All applications are made online via the web page on http://www.osym.gov.tr (OSYM, 2020). 
Table no. 4. Evaluation of the statement after SWP experience that it is difficult to find a job after graduation

\begin{tabular}{|c|c|c|c|c|c|}
\hline & Frequency & $\%$ & $\%$ & $x$ & Median \\
\hline I Completely agree & 88 & 19.3 & \multirow{2}{*}{52.6} & \multirow{2}{*}{3.3729} & \multirow{2}{*}{$\begin{array}{c}4 \\
\text { (I Agree) }\end{array}$} \\
\hline I agree & 160 & 33.3 & & & \\
\hline $\begin{array}{l}\text { Neither agree nor } \\
\text { disagree }\end{array}$ & 102 & 21.3 & 21.3 & Mode & S.D. \\
\hline I don't agree & 103 & 21.5 & \multirow{2}{*}{27.1} & \multirow{3}{*}{$\begin{array}{c}4 \\
\text { (I Agree) }\end{array}$} & \multirow{3}{*}{1.17049} \\
\hline Completely disagree & 27 & 5.6 & & & \\
\hline Total & 480 & 100.0 & 100.0 & & \\
\hline
\end{tabular}

The reason for the former group of students feeling that employment after graduation is easy could be because of their high self-confidence due to deeming themselves successful. The reason for the latter group could be that they had a working relationship before SWP and having the experience of employment and sustaining a working relationship due to this.

When the effects of SWP on students' professional experiences are evaluated, it can be seen that $45.2 \%$ of the students could not gain (adequate) any professional experience after SWP experience. On the contrary, $40.8 \%$ of students express that SWP added professional experience to them. The median score of 2.83 indicates that the professional expertise gained is on an average level. The most used score being 1 and average score being 3 shows that SWP could not make enough contribution to their professional experience (table no. 5).

Table no. 5. Contribution of SWP to professional experience of students

\begin{tabular}{|c|c|c|c|c|c|}
\hline & Frequency & $\%$ & $\%$ & $\bar{x}$ & Median \\
\hline I completely agree & 76 & 15.8 & \multirow[b]{2}{*}{40.8} & \multirow[b]{2}{*}{2.8396} & 3 \\
\hline I agree & 120 & 25.0 & & & $\begin{array}{c}\text { (Nor Agree Nor } \\
\text { Disagree) }\end{array}$ \\
\hline $\begin{array}{l}\text { Neither agree nor } \\
\text { disagree }\end{array}$ & 67 & 14.0 & 14.0 & Mode & S.D. \\
\hline I don't agree & 85 & 17.7 & \multirow{2}{*}{45.2} & \multirow{3}{*}{$\begin{array}{c}1 \\
\text { I Completely } \\
\text { Disagree) }\end{array}$} & \multirow{3}{*}{1.46258} \\
\hline I completely disagree & 132 & 27.5 & & & \\
\hline Total & 480 & 100,0 & & & \\
\hline
\end{tabular}

According to the findings, it is understood that the students were appointed to individual institutions without taking the field of education-work placement correspondence into account. With this lack of relevance and the median score of 2.83 in mind, it is understood that SWP is not an application that provides professional knowledge and skills to students. Furthermore, the 
low ratio of professional skill gains was caused coincidentally, where the field of educationwork placement corresponded well. Meanwhile, it has been requested from the students that to evaluate the SWPs contribution for themselves. Accordingly, the most highly ranked contributions attained by students are getting to know the working life, generating income, and forming good relationships with colleagues, respectively (table no. 6).

Table no. 6. Contributions of SWPs to the Students

\begin{tabular}{|c|c|c|c|c|c|c|}
\hline \multirow{2}{*}{ Contribution } & \multicolumn{2}{|c|}{$\begin{array}{c}\text { Primary } \\
\text { Contribution }\end{array}$} & \multicolumn{2}{|c|}{$\begin{array}{l}\text { Secondary } \\
\text { Contribution }\end{array}$} & \multicolumn{2}{|c|}{$\begin{array}{c}\text { Tertiary } \\
\text { Contribution }\end{array}$} \\
\hline & Frequency & $\%$ & Frequency & $\%$ & Frequency & $\%$ \\
\hline $\begin{array}{l}\text { Getting to know the } \\
\text { working life }\end{array}$ & $\underline{213}$ & $\underline{44.4}$ & 148 & 30.8 & 87 & 18.1 \\
\hline Generating income & 128 & 26.7 & $\underline{156}$ & $\underline{32.5}$ & 152 & 31.7 \\
\hline $\begin{array}{l}\text { Forming good } \\
\text { relationships with } \\
\text { colleagues }\end{array}$ & 51 & 10.6 & 129 & 26.9 & $\underline{161}$ & $\underline{33.5}$ \\
\hline $\begin{array}{l}\text { Gaining practical skills } \\
\text { in my field of study }\end{array}$ & 72 & 15.0 & 32 & 6.7 & 49 & 10.2 \\
\hline Others & 10 & 2.1 & 7 & 1.5 & 13 & 2.7 \\
\hline Unresponded & 6 & 1.3 & 8 & 1.7 & 18 & 3.8 \\
\hline Total & 480 & 100.0 & 480 & 100.0 & 480 & 100.0 \\
\hline
\end{tabular}

The internship practices during one's university education is a relatively short practice that puts the students into the workplace and is similar to SWP in terms of its purpose and application. Because of this similarity, it is expected that a significant difference will emerge between students who have previously practiced internship and did not, in terms of recognizing the labour market. In our study, the ratio of students who have done internships amongst the students who participated in SWP is quite low (17.7\%) (table no. 7). Thus, one can argue that internship activities within the university curricula in which students can gain practical skills by utilizing their technical knowledge is quite limited in Turkey. Even though the GPAs of those who completed internships are high, it is not statistically significant at the 0.05 significance level $(p=0.686>0.05)$. Thus, there is no statistically significant difference between those who have or have not done professional practices such as internships. Looking at table (table no. 7), one can argue that the students have benefited from having a chance to put their knowledge into practice by joining the labour force in terms of knowing the labour market. It is argued that the longer workplace practices are, the more detailed the knowledge students have obtained (Arpat, et al., 2017). 
Table no. 7. The correlation between internship experience-SWP in terms of getting to know the workplace

\begin{tabular}{|c|c|c|c|c|c|c|c|}
\hline $\begin{array}{l}\text { Doing } \\
\text { Internship }\end{array}$ & Frequency & $\%$ & $\bar{x}$ & S.D. & $t$ & $d f$ & $p$ \\
\hline Yes & 85 & 17.7 & 4.0118 & 0.66358 & \multirow{4}{*}{0.405} & \multirow{4}{*}{478} & \multirow{4}{*}{0.686} \\
\hline No & 395 & 82.3 & 3.9747 & 0.78654 & & & \\
\hline \multirow{2}{*}{ Total } & \multirow{2}{*}{480} & \multirow{2}{*}{100.0} & \multicolumn{2}{|c|}{ Levene's $p$} & & & \\
\hline & & & \multicolumn{2}{|c|}{0.681} & & & \\
\hline
\end{tabular}

At the same time, university internships are criticized for not helping to gain professional skills due to their shortness. When the effects on professional gains obtained by internships and SWP are examined, it can be said that there is no statistically significant difference between the two groups regarding gaining professional experience $(\mathrm{p}=0.959>0.05)$. Thus, all students, whether they have completed internships or not, obtain similar professional gains from SWP (table no. 8).

Table no. 8. The internship-SWP correlation in terms of gaining job experience

\begin{tabular}{|c|c|c|c|c|c|c|c|}
\hline $\begin{array}{l}\text { Doing } \\
\text { Internship }\end{array}$ & Frequency & $\%$ & $\bar{x}$ & S.D. & $t$ & $d f$ & $p$ \\
\hline Yes & 85 & 17.7 & 2.8471 & 1.41847 & \multirow{4}{*}{0.052} & \multirow{4}{*}{478} & \multirow{4}{*}{0.959} \\
\hline No & 395 & 82.3 & 2.8380 & 1.47365 & & & \\
\hline \multirow{2}{*}{ Total } & \multirow{2}{*}{480} & \multirow{2}{*}{100.0} & \multicolumn{2}{|c|}{ Levene's $p$} & & & \\
\hline & & & \multicolumn{2}{|c|}{0.399} & & & \\
\hline
\end{tabular}

In the other hand, the average scores of students who have prior work experience to SWP on the getting to know the labour market is lower than students without experience. The difference between the groups is statistically significant (\%95 significance value, $\alpha=0.05$ margin of error, $\mathrm{p}=0.041<0.05$ ) (table no. 9).

Table no. 9. The effect of prior work practice on getting to know the labour market

\begin{tabular}{|c|c|c|c|c|c|c|c|}
\hline $\begin{array}{l}\text { Working } \\
\text { State }\end{array}$ & Frequency & $\%$ & $\bar{x}$ & S.D. & $t$ & $d f$ & $p$ \\
\hline Yes & 182 & 37.9 & 3.8901 & 0.82033 & \multirow{4}{*}{-2.045} & \multirow{4}{*}{478} & \multirow{4}{*}{0.041} \\
\hline No & 298 & 62.1 & 4.0369 & 0.72612 & & & \\
\hline \multirow{2}{*}{ Total } & \multirow{2}{*}{480} & \multirow{2}{*}{100.0} & \multicolumn{2}{|c|}{ Levene's $p$} & & & \\
\hline & & & \multicolumn{2}{|c|}{0.102} & & & \\
\hline
\end{tabular}


In this context, considering the effects of previous work experiences on professional skill acquisition are evaluated. According to that, the average scores of gaining professional experience for students who have no prior work experience is higher than students who had prior job experience (table no. 10). But this difference is not statistically significant $(95 \%$ significance value, $\alpha=0.05$ margin of error) ( $p=0.488>0.05)$. Thus, it is not possible to say that having working experience before SWP makes a meaningful contribution towards gaining professional experience.

Table no. 10. The effect of prior work practice on gaining professional skills

\begin{tabular}{|c|c|c|c|c|c|c|c|}
\hline $\begin{array}{l}\text { Previous } \\
\text { Work } \\
\text { Experience }\end{array}$ & Frequency & $\%$ & $\bar{x}$ & S.D. & $t$ & $d f$ & $p$ \\
\hline Yes & 182 & 37.9 & 2.7802 & 1.48512 & \multirow{4}{*}{-0.695} & \multirow{4}{*}{478} & \multirow{4}{*}{0.488} \\
\hline No & 298 & 62.1 & 2.8758 & 1.44996 & & & \\
\hline \multirow{2}{*}{ Total } & \multirow{2}{*}{480} & \multirow{2}{*}{100.0} & \multicolumn{2}{|c|}{ Levene's $p$} & & & \\
\hline & & & \multicolumn{2}{|c|}{0.258} & & & \\
\hline
\end{tabular}

Considering the relationship between the SWP students' field of study and their assigned work placement, it is seen that the students' assigned workplaces and their fields of study are largely unrelated or poorly connected $(57.5 \%)$ (table no. 11). These scores shed light on the reason why students participating in SWP claim not to have had professional contributions.

Table no. 11. The relationship between SWP and the field of study

\begin{tabular}{|c|c|c|c|c|c|}
\hline $\begin{array}{l}\text { Education-Work } \\
\text { placement } \\
\text { relationship }\end{array}$ & Frequency & $\%$ & $\%$ & $\bar{x}$ & Median \\
\hline No Relationship & 181 & 37.7 & \multirow[b]{2}{*}{57.5} & \multirow[b]{2}{*}{2.3625} & 2 \\
\hline Poor Relationship & 95 & 19.8 & & & $\begin{array}{c}\text { Poorly } \\
\text { Connected }\end{array}$ \\
\hline $\begin{array}{l}\text { Average } \\
\text { Relationship }\end{array}$ & 102 & 21.3 & 21.3 & Mode & S.D. \\
\hline High Relationship & 53 & 11.0 & \multirow[b]{2}{*}{21.2} & \multirow{3}{*}{$\begin{array}{c}1 \\
\text { No Relationship }\end{array}$} & \multirow{3}{*}{1.34996} \\
\hline $\begin{array}{l}\text { Very High } \\
\text { Relationship }\end{array}$ & 49 & 10.2 & & & \\
\hline Total & 480 & 100.0 & & & \\
\hline
\end{tabular}

Also, the open-ended questions base on participants' non-quantitative observations show that there are differences among students of social sciences, STEM students, and life sciences and languages in terms of field of study-work placement relationship. While there is a closer relationship between work placement and field of study for students in the field of social sciences, this relationship is weakened for mathematics, engineering, languages, medicine and nursing schools students (figure no. 3). 
The Relationship Between the Work Placement and Field of Study

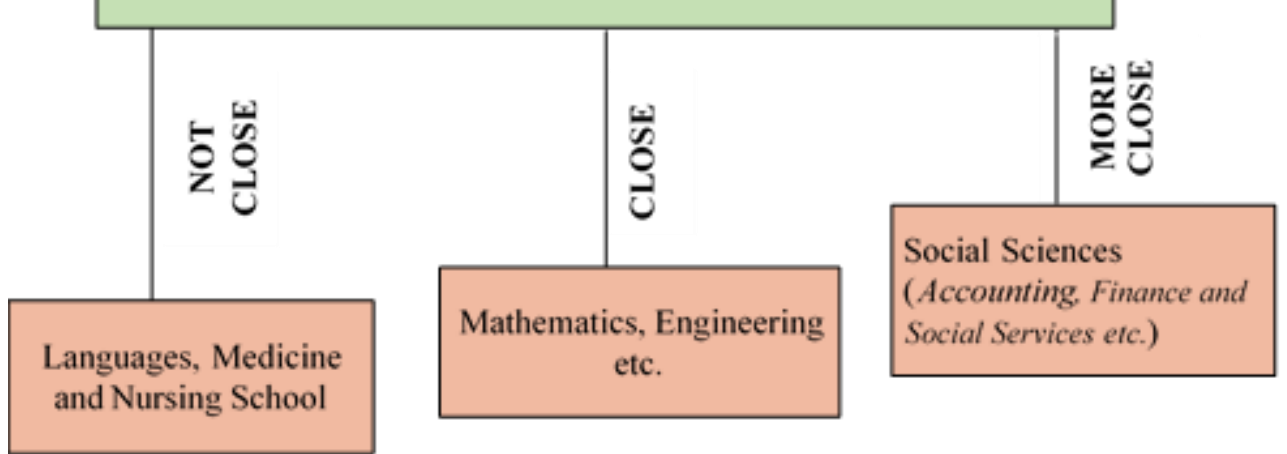

Figure no. 3. Work placement and field of study relationship

In terms of work placement relevance, students majoring in social sciences said that the jobs they did were more closely related to their fields of study. For example, a male participant aged 23 from Ankara stated I'm studying sociology. I've worked in social services, and the job I've worked was closely related to my major. Additionally, students who have worked in humanities and social sciences areas such as psychology, social services, and call centers have higher scores on the field of study-work placement correspondence. On the other hand, students who have been studying engineering, science and languages complain about having little overlap between their field of study and the work placement. For example, while a $21-$ year-old female participant from Ankara says I'm studying Molecular Biology and Genetics. I've been appointed to a nursing home. I've made photocopies of documents and filled in record books all through my work experience. Another 20-year-old female participant from Burdur has stated that there is no relationship between my work placement and the field of my study. I'm studying Teachers of English to Speakers of Other Languages (TESOL). The institution I've worked at was a youth center. If you ask me what I did, I've served tea and copied documents... The word cloud gathered from the students' assessments of SWP also supports these statements (figure no. 4).

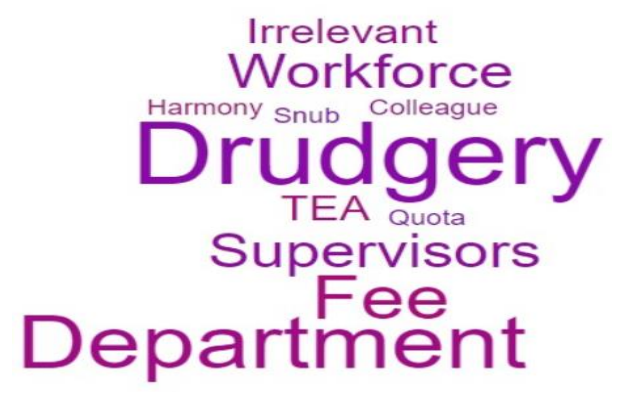

Figure no. 4. The participants' assessment of SWP in word cloud

The students express in their assessment of SWP that they have been appointed to places without field of study-work placement relationship. Also they define workplace practices as drudgery work which is not related to their field of study. 
The students also state that they have been through problems with the appointment process of TEA, have not paid (on time), and have had specific issues with other colleagues and administrative groups. The other issues expressed by the students have been thematically grouped as follows

- Problems about socio-economic rights

- Problems with the application

- Problems related to the working life

- Problems about occupational health and safety

\section{Conclusion and recommendations}

Just as in the global economy, youth unemployment consists of a significant problem in Turkey as well, and the effectiveness of the ALMP practices gradually gains greater importance. SWP is known as an older ALMP practice, however, with a new aspect of appointing university graduates. SWP has first implemented during the 2019 summer period. Since then, SWP has been assessed as useful and practical by the students, who will be part of the labour force in the near future, in helping them get to know and experience the labour market, generating income and having positive social interactions with other workers. However, as the results of our field research show, SWP has been largely ineffective on gaining professional skills with its practical dimension. Appointment of the students to their workplaces without considering education-work placement relationship is prominently evaluated as the main reason for this situation.

In general, SWP is an ALMP which is derived from PBP, is being carried out for the university students to get to know the working life and gain professional discipline. However, employing university graduates within public service solely for this purpose is not possible to make a significant contribution to the fight against youth unemployment. When we consider the reasons why students do not have the necessary skills for employment, we can say that SWP is inadequate for solving this problem. In this aspect, SWP has to be redesigned to help students obtaining skills relevant to their field of study. This is necessary to make SWP a practical application and to utilize public funds optimally.

In our study the results indicate that students regard getting to know the work market as a more significant advantage than getting paid. Regardless, university students still assess SWP as an essential practice to create solutions to possible unemployment problems. Hence, the field of study-work placement relationship and other improvements to SWP may help it become a practical application that eases the transition into working life post-graduation and helps increase youth employment. So, this can make significant contribution to solve the current socio-economic problem rooted in youth unemployment. However, appointing students with careful consideration of the field of study-work placement correspondence is not possible since the application only includes jobs related to preserving nature, restoration, protection and introduction of cultural heritage, the maintenance and order of libraries and supporting the cultural and social services of public institutions. Since social services are allotted only a small part of the overall budget in current economies, it is not possible to ensure a high field of study-work placement relationship for all students even if all public workplaces are included within the scope. 
In this context, private sector workplaces could be included within the scope. If the application is made in the same period of the year, economic incentives can be given to workplaces such as premiums and tax reductions. Thus, professional skill development and cost advantages can be obtained. Furthermore, students may obtain high quality vocational skills, abilities, and experience with practices available in the private sector. More students may have access to this program with the economic benefits obtained. Thus the macroeconomic indicators of Turkey could get better, and socio-economic problems could be solved. Also, it could also be possible that student-private sector interactions could be increased, and universities could obtain information about the expectations regarding the skills-abilities of the labour market and update their curricula accordingly with the collaboration of universities and the industry. The practical implementation of the program could also provide cost advantages. Especially, it reduces the training costs of workplaces such as orientation processes for the students post-graduation.

Some universities in Turkey arrange work placement opportunities for their students under the name of on-the-job training to gain skills-qualifications and get to know the working life within the private sector for 14-16 weeks (per semester). These placements cannot take place at public institutions, and few students utilize this opportunity since it is not part of their universities' curricula. By merging the on-the-job programs with SWPs under the coordination of TEA and financing them with public funds, significant gains could be obtained in terms of designing SWP to have an effective content and fighting against youth unemployment. When employers need new labour, they will select people who have experience before in their own company under the SWP instead of training new employees which will decrease youth unemployment and make important contributions towards fighting structural unemployment. To combat with youth unemployment, further research is needed and it should be carried out within the frame of specifying the procedures and principles of merging job training with the SWP practices of the public authorities as per the benefits discussed in this paper. Briefly, SWPs, which aim to get to know the labour market and to provide professional skills, it should also have an education-work harmony and cover private sector workplaces and all students.

\section{References}

Aksit, A., Arpat, B. and Kalfa, V.R., 2017. Analysis of the Conribution to Professional Knowledge of the Job Training within the Student Perspective in the $3+1$ Education Model-The Example of the Honaz Vocational School. European Scientific Journal, Special Iss., pp.176-192.

Akyildiz, Y., 2019. İşsizlik ve İşkur'un Aktif İstihdam Politikaları. Akademik Bakış Dergisi, 71, p.94-119.

Alpar, R., 2011. Uygulamalı Çok Değişkenli İstatistiksel Yöntemler. 3rd ed. Ankara: Detay Yayıncilik.

Arpat, B., 2020. Social Work Program as an Active Employment Policy: An Application on University Students. Manas Journal of Social Studies, 9(1), pp.327-340.

Arpat, B., 2018. Türkiye'de Genç İşsizlikle Mücadelede Meslek Yüksekokullarında Uygulanan İşbaşı Eğitimlerinin Rolü ve Önemi: Honaz MYO Örneği. Çalışma ve Toplum, 59, pp.2193-2229. 
Arpat, B., Kalfa, V.R., Aksit, A. and Camurdan, B., 2017. Meslek Yüksekokullarında Nitelikli Ara Eleman İhtiyacını Karşılamada Yeni Arayışlar: 3+1 İşbaşı Eğitimi ModeliHonaz Meslek Yüksekokulu Örneği. Çalışma İlişkileri Dergisi, 8(2), pp.76-94.

Askin, A. and Askin, O.A., 2017. Aktif İstihdam Politikası Olarak Toplum Yararına Programlar: Tokat İli Araştırması. Gazi İktisat ve İşletme Dergisi, 3(3), pp.1-16.

Ata, N., 2007. Türkiye'de İşü̈cünün Yapısı ve Genç İşsizlik. TİSK Akademi, 2(1), pp.109-118.

Baki, A. and Gokcek, T., 2012. Karma Yöntem Araştırmalarına Genel Bir Bakış. Electronic Journal of Social Sciences, 11(42), pp.1-21.

Balta, A.T., 2007. As a Function of Human Resources Management Wage Administration, Motivation and an Application. MA. Marmara University.

Bozdaglioglu, E.Y.U., 2008. Türkiye'de İşsizliğin Özellikleri ve İşsizlikle Mücadele Politikalar1. Sosyal Bilimler Dergisi, 20, pp.45-65.

Brown, A. and Koetti, J., 2015. Active Labor Market Programs - Employment Gain or Fiscal Drain?. IZA Journal of Labor Policy, 5(1), pp.1-30.

Caliendo, M. and Schmidl, R., 2016. Youth Unemployment and Active Labor Market Policies in Europe. IZA Journal of Labor Policy, 4(12), pp.1-36.

Cansever, E.B. and Namal, M.K., 2019. İşgücünün Görünmeyen Dezavantajlıları: Ne İşte Ne de Eğitimde Olmayan Gençler. In: M. Koçancı and H. Yerlikaya, eds. 2019. Sosyal Politika ve Çalışma İlişkilerinde Güncel Sorunlar. 2nd ed. Ankara: Gazi Kitabevi, pp.111-134.

Creswell, J.W., 2006. Understanding Mixed Methods Research. (Chapter 1). [online] Sage Publication. Available at: <http://www.sagepub.com/upm-data/10981_Chapter_1.pdf > [Accessed 18 November 2018].

Dar, A. and Tzannatos, Z., 1999. Active Labor Market Programmes, A Strategy for Poverty Alleviation: The Gender Dimension, Development and Technical Cooperation Department. Issues in Development Discussion Paper, No.10. Geneva: ILO.

Erhel, C., Gautie, J., Gazier, B. and Morel, S., 1996. Job Opportunities For The Hard-to-place. In: G. Schmid, J. O'Reilly and K. Schömann, eds. 2019. International Handbook of Labour Market Policy and Evaluation. Cambridge: Cambridge Publishing, pp.277-308.

Erkol, S., 2012. İşsizliğin Sosyal Dişlanma Üzerine Etkisi. TÜHíS İş Hukuku ve İktisat Dergisi, 24(3-4-5), pp.46-70.

Evans-Klock, C., Kelly, P., Richards, P. and Vargha, C., 1998. Worker Displacement: Public Policy and Labor Management Initiatives in Selected OECD Countries. Employment and Training Papers, No.24. Geneva: ILO.

Gun, S., 2013. Toplum Yararına Çalışma Programı: İşsizlikle Mücadelede Yeni Bir Yöntem mi?. Sosyal Güvenlik Dergisi, 3(2), pp.76-95.

Gundogan, N., 2013. Çalışma Ekonomisine Giriş ve Temel Kavramlar. In: N. Gündoğan and K. Biçerli, eds. 2013. Çalışma Ekonomisi-1. Yayın No:2675. Eskişehir: Anadolu Üniversitesi Yayını.

Guney, K., 2019. The Problem and the Resources of Youth Unemployment in European Union and Turkey. MA. Cukurova University.

Gursel, S. and Ulusoy, V., 1999. Türkiye'de İssizlik ve İstihdam. 1. Baskı. İstanbul: Yapı ve Kredi Yayınları. 
ILO, 2015. Gençlerde Küresel İstihdam Eğilimleri 2017. [online] Available at: <http://www.ilo.org/ankara/news/WCMS_600486/lang--tr/index.htm> [Accessed 10 October 2019].

Isik, V., 2019. Toplum Yararına Program (TYP) Yeni Bir Model Önerisi. İstanbul: Seta Analiz Seta Vakfi.

Izgi, B.B., 2012. Genç İşsizliği ve Eğitim ile Olan İlişsisi. Elektronik Sosyal Bilimler Dergisi, 11(41), pp.295-310.

Johnson, B. and Turner, L.A., 2003. Data Collection Strategies in Mixed Methods Research. In: A. Tashakkori and C. Tedlie, eds. 2003. Handbook of Mixed Methods in Social and Behavioral Research. Thousand Oaks, CA: Sage. pp.297-319.

Johnson, R.B. and Onwueguzie, A.J., 2004. Mixed Methods Research: A Research Paradigm Whose Time has Come. Educational Researcher, 33(7), pp.14-26.

Kaboub, F., 2007. Employment Guarantee Programs: A Survey of Theories and Policy Experiences. The Levy Economics Institute of Bard College. Working Paper no. 498.

Kapar, R., 2005. Aktif İşgücü Piyasası Politikaları. İstanbul Üniversitesi İktisat Fakültesi Mecmuasl, 55(1), pp.341-371.

Karadeniz, O. and Kumas, H., 2016. Meslek Yüksekokulu Öğrencilerinin İstihdam Edilebilirliğini Arttırmada Mesleki Uygulamalar Dersi (3+1 Programlarının) ile İŞKUR İşbaşı Eğitim Programlarının Rolü: Honaz MYO Örneği. In: UMYOS, 5th International Vocational Schools Symposium (UMYOS 2016). Prizren, Kosova, 18-20 May 2016. S.1:s.n.

Koklu, A., 1984. Makro Iktisat. Ankara: S yayınları.

Krejcie, R.J. and Morgan, D.W., 1970. Determining Sample Size For Research Activities. Educational and Psychological Measurement, 30, pp.607-610.

Kumas, H., 2001. The Psychosocial Dimension of Unemployment and It's Efect's on the Value of Work Life. PhD. Dokuz Eylul University.

Lerman, R.I., 2013. Are Employability Skills Learned in U.S. Youth Education and Training Programs?. IZA Journal of Labor Policy, 2(6), pp.1-20.

Marques, P. and Hörisch, F., 2019. Understanding Massive Youth Unemployment During the EU Sovereign Debt Crisis: A Configrational Study. Comparative European Politics, pp.1-23.

Ministry of Family, Labor and Social Services, 2017. Ulusal İstihdam Stratejisi (2014-2023) ve Eylem Planlarl Kitabl. [online] Available at: <http://www.uis.gov.tr/ announcements/27102017/> [Accessed 28 January 2020].

Murat, S. and Sahin, L., 2011. Gençlerin İstihdamı/İşsizliği Bakımından Türk Eğitim Sisteminin Değerlendirilmesi. Çalışma ve Toplum, 3, pp.93-135.

Nunnaly, Jum C., 1978. Psychometric Theory, 2nd ed. New York: Mc Graw-Hill.

OECD, 2017. OECD Employment Outlook 2017. [online] Available at: <http://www.oecd.org/ els/oecd-employment-outlook-19991266.htm> [Accessed 28 July 2019].

Okursoy, A. and Turan, A.H., 2014. An Empirical Examination to Define Factors Affecting Customers' Satisfaction Perceptions at a University Cafeteria. Doğuş Üniversitesi Dergisi, 15(1), pp.65-78. 
OSYM, 2020. 2020 Higher Education Institution Exam (2020-YKS) Frequently Asked Questions. [online] Available at: <https://dokuman.osym.gov.tr/pdfdokuman/2020/ YKS/sss06022020.pdf/> [Accessed 15 June 2020].

Ozdemir, D., 2019. İşsizliğin Azaltılmasında Kamusal Bir İstihdam Modeli Olarak Nihai İşveren Programı. Manas Sosyal Araştırmalar Dergisi, 8(3), pp.2539-2558.

Ozdemir, M.C., 2012. Türkiye'de İstihdam ve İşsizlik. In: M.K. Biçerli and V.C. Özgüler, eds. 2012. İstihdam ve İşsizlik. No. 2678. Eskişehir: Anadolu Üniversitesi Yayını.

Ozguler, V.C., 2019. Beşeri Sermaye Teorisi ve İşgücü Piyasaları. In: H. Bal, ed. 2019. İktisat Araştırmaları. Ankara: Akademisyen Kitabevi.

Regulation of the Amendment of the Active Workforce Services Code., 2018. Aktif İşgücü Hizmetleri Yönetmeliğinde Değişiklik Yapılmasına Dair Yönetmelik. Turkish Official Gazette. 16 Nov. Number:30597.

Saribiyik, M., 2013. Meslek Yüksekokullarında Nitelikli İşgücü Yetiştirmek için 3+1 Eğitim Modeli. Akademik Platform Mühendislik ve Fen Bilimleri Dergisi, 1, pp.39-41.

Secer, B., 2006. Genç İşsizliği: Eğitim ve İstihdamda Sorunlar, Çözüm Arayışları. Tisk Akademi, Özel Say1-1, pp.271-305.

Tas, H., Kuçukoglu, M. and Demirdogmez, M., 2018. Türkiye'de Genç İşsizlik Sorunu ve Çözüm Önerileri. Hak-İs Uluslararası Emek ve Toplum Dergisi, 7(18), pp.280-294.

TEA, 2019a. Haziran Ayı Bülten Tablosu. [online] Available at: <https://www.iskur.gov.tr/ kurumsal-bilgi/istatistikler/ "Tablo 3" $>$ [Accessed 25 January 2020].

TEA, 2019b. 30 Soruda Sosyal Çalışma Programı. [online] Available at: <https://www.iskur.gov.tr/is-arayan/kurs-ve-programlar/sosyal-calisma-programi/> [Accessed 25 January 2020].

TURKSTAT, 2020a. Hanehalkı İşücü İstatistikeri - Analitik Çerçeve, Kapsam, Tanımlar ve Sinfflamalar. [online] Available at: <http://www.tuik.gov.tr/PreTablo.do?alt_id= 1007> [Accessed 28 July 2020].

TURKSTAT, 2020b. Işsücü İstatistikleri, Şubat 2020. [online] Available at: <http://www.tuik.gov.tr/HbGetirHTML.do?id=33786> [Accessed 28 June 2020].

Tutar, H., 2020. Bilimsel Düşünme ve Araştırma Yöntemleri. In: S. Unal, ed. 2020. Sosyal Bilimlerde Araştırma Yöntemleri. Erzurum: Atatürk Üniversitesi Açık Öğretim Fakültesi Yayın1, pp.48-71.

Usen, S., 2007. Avrupa Birliği Ülkeleri ve Türkiye'de Aktif Emek Piyasası Politikaları. Çalışma ve Toplum, 2(13), pp.65-95.

Vazquez-Alvarez, R., 2004. The Economics of Active Labor Market Policies. [online] Available at: <https://www.researchgate.net/publication/237366388_The_Economics_ of_Active_Labor_Market_Policies>[Accessed 12 May 2020].

Yavuz, A., 2010. Çalı̧̧ma Ekonomisi. İstanbul: İstanbul Üniversitesi Açık ve Uzaktan Eğitim Fakültesi.

Yurekli, E. and Kalfa, V.R., 2016. Stajyer Öğrencilerin Mesleki Atılganlık Düzeylerinin Araştırılması; PAÜ Honaz Meslek Yüksekokulunda Bir Alan Araştırması. In: s.n., ISVET 2016. S.1., 12-15 October 2016. Çorum: Hitit Üniversitesi Yayınları.

Zaim, S., 1997. Çalışma Ekonomisi. 10. Basım. İstanbul: Filiz Kitabevi. 